\title{
The status of Diversity and Species Composition of Crabs in Navanthurai Coastal Area in Jaffna Peninsula of Sri Lanka
}

\author{
N. Tharmine*, U. Edrisinghe ${ }^{1}$ and K. Sivashanthini ${ }^{2}$ \\ Postgraduate Institute of Agriculture \\ University of Peradeniya \\ Sri Lanka
}

\begin{abstract}
Crabs are economically important and a protein rich commodity in the coastal as well as offshore fisheries in Sri Lanka. Crabs are one of the potential aquaculture candidates and also form important commercial and recreational fishery. The present study was conducted with the aim of documenting the species composition and diversity of crabs inhabiting in the Navanthurai coastal area of Jaffna peninsula of Sri Lanka. The current investigation was carried out from November 2011 to October 2012 in Navanthurai coastal waters, which is a part of the Jaffna estuary situated between latitudes $9^{\circ} 36^{\prime}-9^{\circ} 50^{\prime}$ North and longitudes $79^{\circ} 40^{\prime}-80^{\circ} 40^{\prime}$ East. Specimens were collected using different types of nets; mainly driftnet, gill net, hoop net and 'Sirahuvalai'. All crabs were brought to the laboratory and identified up to species level based on the morphological characters. Accordingly, five edible species of crabs namely; Scyllaserrata, Portunus pelagicus, Thalamita craneta, Charybdis notator and Portunus sanguinolentes, belong to four genera of the family Portunidae were recorded. . Among them P.pelagicus is the dominant species contributing

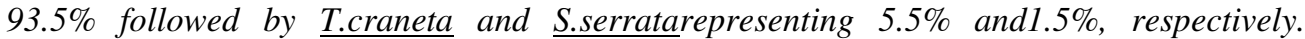
However, S.serrata is the most demanded species of crabs both for local and export markets. Only a few individuals of C.natator and P.sanginolentus were observed representing $0.37 \%$ and $0.13 \%$,respectively of the harvest. The information and observations in this study will be of use in formulating management policies for the crab fishery off the Navanthurai coastal area.
\end{abstract}

Keywords: Coastal waters, crab, estuary, species composition

\section{INTRODUCTION}

Crabs are one of the most important coastal aquatic species worldwide because of its high consumer demand that leads to fetch a high price both in local and export markets (Chitravadivelu, 1994). They also form an important constituent in the marine fish landings in the world. Crabs are a good protein source to man as well as marine life. Crab meat is relished as a delicacy and is rich in vitamins. Hence, it is believed to carry therapeutic qualities for colds, asthma and wheezing.

Navanthurai coastal area is situated in the Northern part of Sri Lanka between latitudes $9^{0}$ $36^{\prime}-9^{0} 50^{\prime}$ North and longitudes $79^{0} 40^{\prime}-80^{\circ} 40^{\prime}$ East, of Jaffna estuary. Jaffna estuary is a

\footnotetext{
Department of Animal Science, Faculty of Agriculture, University of Peradeniya, Sri Lanka

Department of Zoology, Faculty of Science, University of Jaffna, Sri Lanka

Corresponding author: tharmine29@gmail.com
} 
shallow coastal water body, resourceful when compared to other parts of the country (Sachithananthan and Perera, 1970).

Eight species of edible crabs have been recorded from northern part of Sri Lanka (Sivashanthini and Chandrika, 2006). However, Chitravadivelu (1994) has reported only three species of crabs, C. annulata, S. serrata and P. pelagicusin in Jaffna estuary. The three species of crabs, which contribute significantly to the commercial brackish water catches are $P$. pelagicus, $S$. serrata, and $P$. sanguinolentis. However, the crab culture industry now concentrates only on species $S$. serrata.

The present study was undertaken to identify and update the crab species and their composition in Navanthurai coastal Area in Jaffna, Sri Lanka.

\section{MATERIALS AND METHODS}

The fish samples were collected from Navanthurai coastal area in Jaffna district in Northern Province (Fig. 1). Crabs were collected weekly from November 2011 to October 2012, by different types of nets mainly driftnet, gill net, hoop net and 'Sirahuvalai' which are used in commercial fishing around the Navanthurai coastal area. The colouration of body and markings were recorded in fresh condition. They were brought directly to the laboratory of the Department of Fisheries, University of Jaffna for detailed analysis. Identification of species were done according to the standard literature (De Bruin et al., 1994) on their morphological characters (Carpenter and Niem, 1998). The morphological characters include teeth in frontal and anterio-lateral margin in the carapace, longitudinal or transverse sutures, type of carapace, number of spines, and colour, markings and number of spines in merus, carpus and palm of the cheliped.

Identified specimens were preserved in the museum of the Department of Fisheries, University of Jaffna. Photographs of crabs were taken to show their external morphology. 

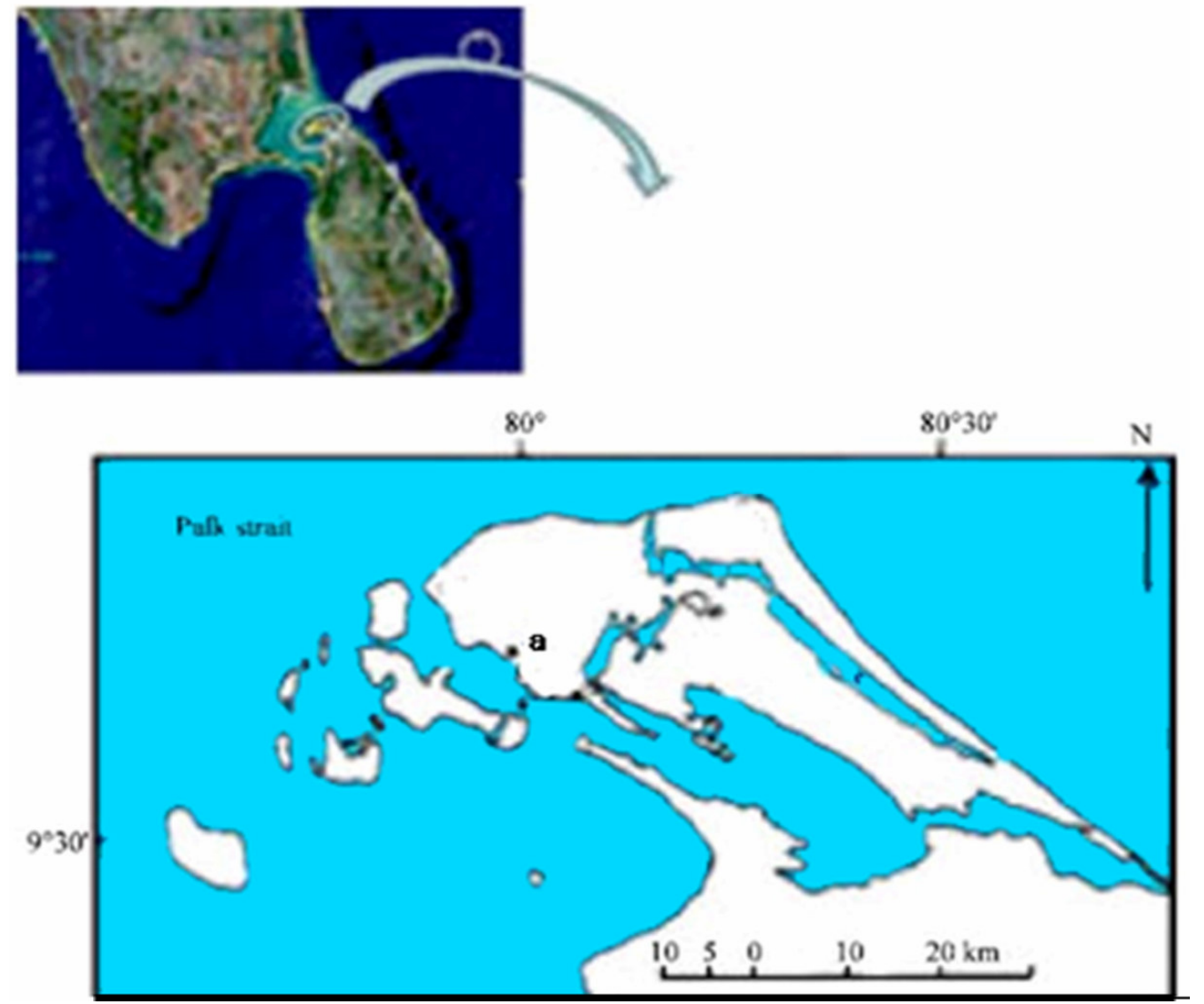

Fig. 1. Location of the study area in the Jaffna Lagoon (a-Navanthurai)

\section{RESULTS AND DISCUSSION}

Crab fishing is done throughout the year and the present study was conducted for a total one year period covering different seasons of the year. In the present investigation, 5 species of crabs, namely $P$. pelagicus, $S$. serrata, $T$. cranata, $C$. notate and $P$. sanguinolentis were observed (Figs. 2 to 6). Species-wise crab composition at Navanthurai coastal water, Jaffna showed that $P$. pelagicusis the dominant species contributing $93.5 \%$, followed by $T$. cranata and S. serrata consisting 5.5\%, 1.5\%, respectively. However, S. serrata is the most demanding species in local and export markets. Only a few $C$. notator and $P$. sanguinolentus were captured during the study period. The annual contribution of species $P$. sanguinolentus, C. notator was $0.37 \%$ and $0.13 \%$, respectively (Fig. 7). 
Tharmine et al.

Species Thalamitacrenata (Latreille, 1829)

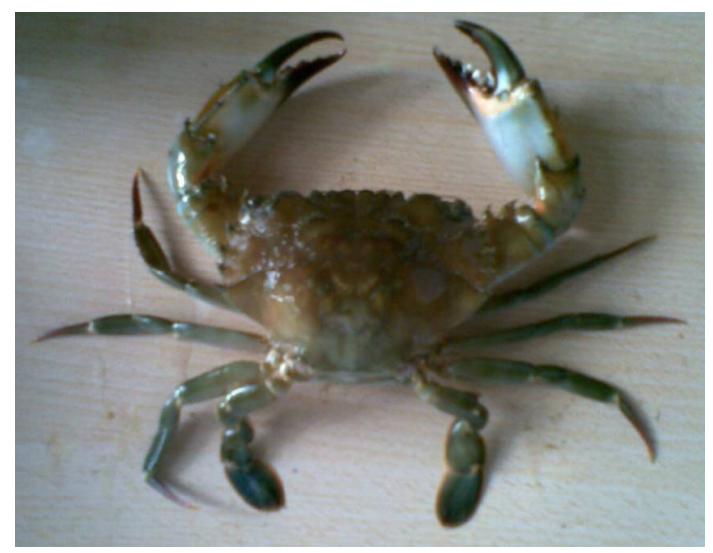

Fig. 2. Thalamitacrenata - Common name: Crenatatedthalamita

Colour of $T$. crenata consists of uniform greenish grey carapace and pinkish claws with dark brown tips, white extreme tips.

The anterior region (front) cut into nearly six equal lobes and well separated from the broad supra orbital angle. A single transverse ridge crosses between the last spines of the anterio lateral spine.

Species Portunuspelagicus (Linnaeus, 1758)

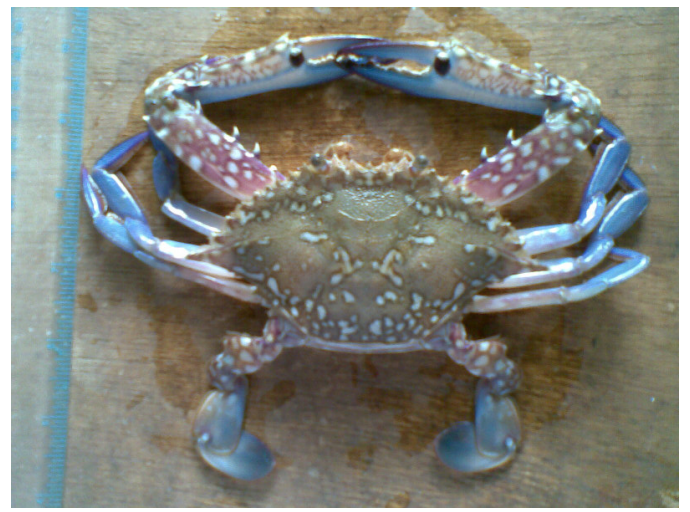

Fig. 3. Portunuspelagicus-Common name: Blue swimming crab

Colour of the male P.pelagicu s is pinkish-blue with extensive irregular white spots. The tips of the chelae and the distal segments of the legs are purple. Females are brownish colour with irregular patches.

The anterio-lateral boarder cut into ninth teeth. The last pair of lateral spine greatly pronounced. A single spine present at the distal end of posterior boarder of merus of the cheliped. 


\section{Species Charybdis notator}

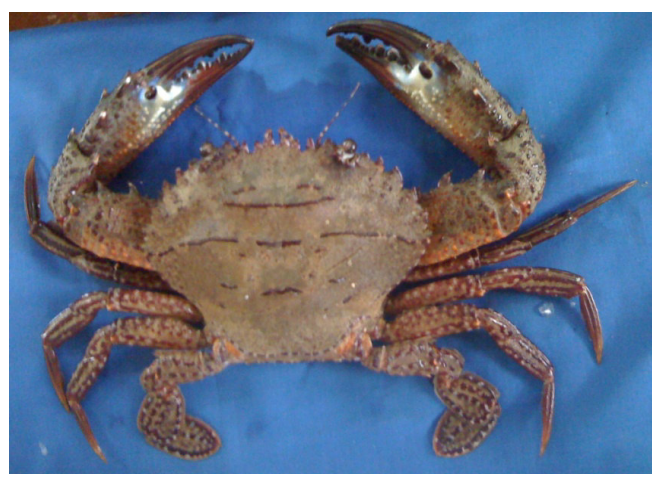

\section{Fig. 4. Charybdis notator}

Colour of $C$. notator is pale brown. Reddish brown tubercles scattered along the body. Dorsal surface of the carapace uniformly covered with soft woolly texture and marked with several reddish granulated transverse ridges.

In anterio- lateral boarder six teeth. The undersurface of the palm of the cheliped is uniformly covered with scaly ridges marked with longitudinal groove.

Species Neptunussanguinolentes (Herbst, 1796)

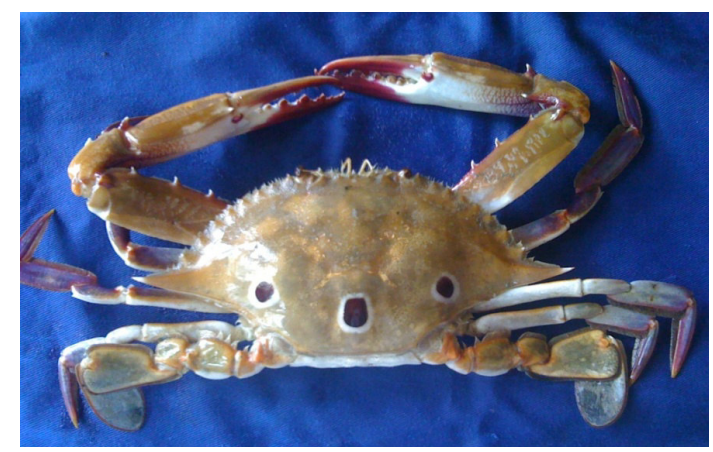

Fig. 5. Neptunussanguinolentes-Common name: Blood spotted swimming crab

Colour of $N$. sanguinolentes is brown with three blood spot ringed with white on the carapace, tip of the claw is red and other legs are blue in colour.

Anterio-lateral boarder of the carapace is cut into nine equal size teeth of which last spine outwardly produced into large sharp spine. Anterior of the carapace finely granulated. 
Tharmine et al.

Species Scylla serrate (Forskal, 1755)

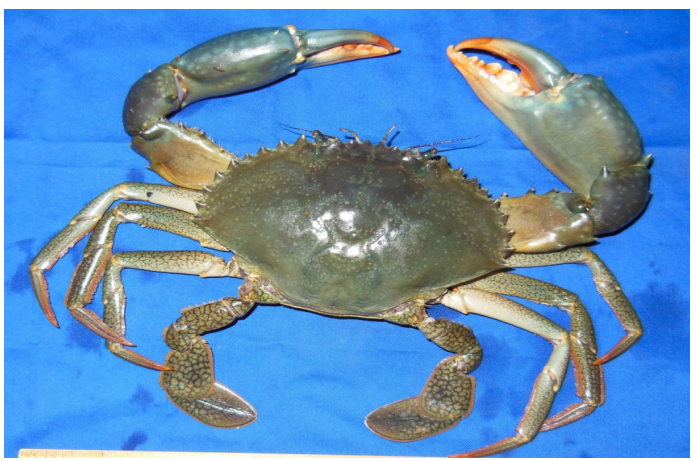

Fig. 6. Scylla serrate-Common name: Mud crab

S. serrate consists of orange colour cheliped (claw) tip and green to almost black body.

The presence of polygonal markings on all limps and the two sharp spine on the outer margin of the carpus of the cheliped. Teeth of the anterio-lateral boarder of the carapace cut into nine. Legs are marbled. Smooth transverse ridges are present in the carapace.

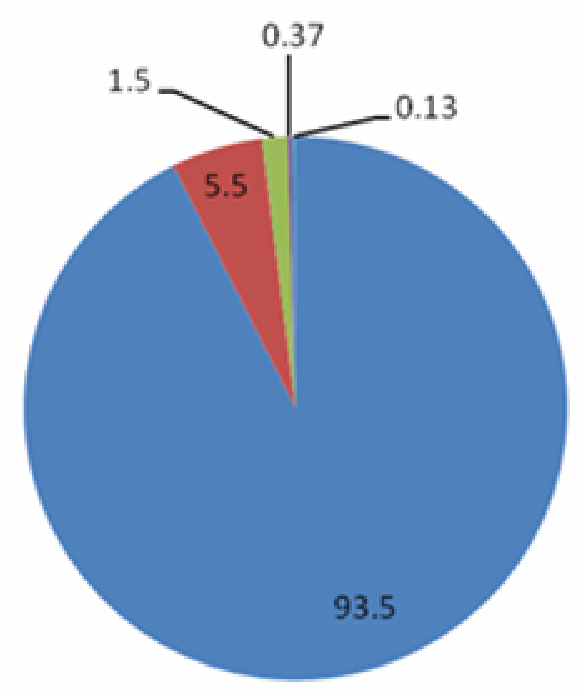

- Portunus pelagicus

Thalamitacrenata

- Scylla serrata

- Charybdis notator

Portunus sanguinolentes

Fig. 7. Composition of Crab species at Navanthurai coastal water, Jaffna

\section{CONCLUSIONS}

The study revealed that at least five species of crabs belong to family portunidae are present in Navanthurai Coastal Area in Jaffna, Sri Lanka. These species are recorded for the first 
time in Navanthurai coastal area. The findings on the crabs diversity in the area contribute in formulating tools for conservation planning in Jaffna estuary region. Further ecological and biological studies on crabs are necessary to investigate the factors which influence the pattern of distribution and implementation of appropriate conservation strategies to the existing species.

\section{REFERENCES}

Carpenter, K.E. and Niem, V.H. (1998). FAO species identification guide for fishery purposes.The living marine resources of the Western Central Pasific. Volume 2. Cephalopods, crustaceans, holothurians and sharks. Rome, FAO. Pp687-1396.

Chitravadivelu, K. (1994). Aspects of fishery and species composition of edible crabs in the Jaffna lagoon. J.Natn. Sci. Coun. Sri Lanka, 21(1), 43 - 55.

De Bruin, G.H.P., Russell, B.C. and Bogush, A. (1995). The Marine Fishery Resources of Sri Lanka, FAO Species Identification Field Guide for Fishery Purposes. Rome, FAO, 400.

Sachithananthan, K. and Perera, W.K.T. (1970). Topography and substratum of the Jaffna lagoon, Bulletin of the fisheries research station Ceylon, 21(2), 75 - 85. 